\title{
UNITED STATES FINANCIAL INSTITUTION RESOLUTION SYSTEM AS A POSSIBLE INSPIRATION FOR THE EUROPEAN UNION
}

\author{
Vít Kropjok $^{1}$
}

\section{Faculty of Law, Charles University in Prague, Czech Rpublic email: kropjok.v@gmail.com}

KROPJOK, Vít. United States financial institution resolution system as a possible inspiration for the European Union. International and Comparative Law Review, 2014, Vol. 14., No. 1, pp. 55-67. DOI: 10.1515/iclr-2016-0044.

\begin{abstract}
In the current time there are many initiatives that are aimed to protect financial institution clients in the European Union. Current economic and financial crisis has shown that there is a need for common approach in this area. Some proposals have been passed. But there are still some in the bill stage and the deposit guarantee schema is one of them. The aim of the article is therefore to describe briefly and assess the proposed European model. The article also contains comparison with the operating United States model due to the inspiration possibility.
\end{abstract}

Keywords: Deposit Guarantee Schema, European Union, Federal Deposit Insurance Corporation

\section{Introduction}

It has been more than five years since the fall of Lehman Brothers ${ }^{2}$, i.e. five years since the financial crisis has broken not only in the United States. Governments particularly in Western countries responded with full guarantee of deposits and with the financial injections into institutions that were in their opinion „too big to fail", because their collapse could threaten the whole financial system stability. Herewith the banks defaults were warded off but the measures have significantly increased the government deficits. Therefore in order not to let the countries go "bankrupt”, European Central Bank (hereafter „ECB“) and American $\mathrm{Fed}^{4}$ had to start buying in bulk the problem countries' government

1 Department of Financial Law and Finances, Faculty of Law, Charles University in Prague, Czech Rpublic.

2 Lehman Brothers was a global financial services firm known for the largest financial bankruptcy in the United States history. Firm declared bankruptcy on the September 15, 2008 due to the huge subprime mortgage market exposures after regulators refusal to liquidate it.

3 In my opinion Greece has already defaulted, de facto. De iure did not, only because of huge bailout, which furthermore relies on an economy growth that would be hard to carry out.

4 Federal Reserved system or United States Central Bank. 
bonds. Although on the issue in question there has been written a lot, the real question is whether the appropriate measures, which could prevent similar crisis in the future, has been implemented. Due to the financial world globalization and „spillover effect" of problems among economic sectors and countries we wouldn't probably find a sector where the term crisis is not inflected. Despite it at present there are opinions that the financial crisis has been warded off and now it is necessary to ward off the debt one. Although the premise on the debt crisis existence can be accepted, in my opinion, not even the financial crisis has been warded off. In this respect we have to mention in particular the process in the European Union and the United States. Provided we would want to accept the premise on the financial crisis warding off, perhaps it could be so done only in the United States, but even there with reservations. In my opinion it cannot be said on Europe even with reservations. Although I have stated that the whole world experiences the financial and economic crises, it cannot be utterly generalized.

Among individual countries or more precisely mainly among regions there we can see theoretical and practical differences in approach. As I have already mentioned my comparison will be dealing with the United States and the European Union. The reason is the cultural and economic similarity. Also in sociopolitical establishment there can be found similarities despite the fact that the United States are the federation while Europe is created with the unitary states. That is to say that Europe is walking by leaps and bounds to quasi federative system or system of confederacy, if it already did not. Thus the United States can be certainly used as the suitable inspiration for the newly formed federative Europe.

\section{The European Union proposal}

Since the beginning of crisis the European Union has prepared many initiatives in an effort to solve related problems. However the initiatives have appeared before the arisen crisis, nevertheless with respect to very significant economic boom many of them were not accepted. ${ }^{5}$

As the first measure responding to the economic crisis we can mark the establishment of European System of Financial Supervisors (hereinafter "ESFS“) ${ }^{6}$ in January 2011. Although there has been created a broad institutional framework

5 But some legal texts were adopted, see for instance : Directive 2005/60/ES of the European Parliament and of the Council of 26 October 2005 on the prevention of the use of the financial system for the purpose of money laundering and terrorist financing, Directive 2006/48/ES of the European Parliament and of the Council of 14 June 2006 relating to the taking up and pursuit the business of credit institutions (recast), Directive 2006/49/ES of the European Parliament and of the Council of 14 June 2006 on the capital adequacy of investment firms and credit institutions (recast).

6 ESFS („European System of Financial Supervisors“) consists of „European Systemic Risk Board“ and „European supervisory Authorities“. Among the European supervisory authorities there belong „European Banking Authority“, „European Securities and Markets Authority“ and „European Insurance and Occupational Pensions Authority“)

\section{(C) Palacký University Olomouc, Czech Republic, 2014. ISSN 1213-8770 (print), ISSN: 2464-6601 (online).}


but without needed tools, which would ensure its practical implementation and enforcement. Top officials of European Union, however, were aware of, and thus the former governor of the Central Bank of Finland ${ }^{7}$, Erkii Liikanen, along with the others was entrusted to prepare an expert vision that should suppress negative impacts of crisis. The outcome of this group is so called Liikanen's Report, where detailed root cause analysis of problems in which the European Union is can be found including proposals for their solutions. ${ }^{8}$

Liikanen's Report was confirmed in June 2012 by the report of chairmen of the European Council, European Commission, so called Eurogroup ${ }^{9}$ and the President of the ECB.

In this Report there is stated that a stable and prosperous European Monetary Union (hereafter „EMU“) has to be based on four principles, which are:

1. Integrated financial system

2. Unified budget system

3. Integrated economic policy

4. Democratic legitimacy and accountability

These conclusions were also supported by the representatives from the Eurozone countries ${ }^{10}$ and they called upon the European Commission to prepare a legislative proposal. The proposal was announced in the Communication EP from September $12^{\text {th }} 2012$, which is known as „A Roadmap towards a Banking Union" $"$.

Newly created banking union ought to be based on four pillars, as follows:

1. Common regulatory rules ${ }^{12}$

7 „Suomen Pankki“

8 „Report of the European Commission's High-level Expert Group on Bank Structural Reform" Basic recommendations are: 1) Separation of particularly risky activities from the current deposit 2) Strengthening of the supervisor's powers 3) Greater protection for savers during the institution 4) Increased capital requirements for the risky activities.

9 This is regular meeting of euro zone finance ministers. The main goal is the care for Euro and the assets of the European Monetary Union.

10 „The Commission will shortly submit proposals of the single supervisory mechanism based on article 127, par 6 . Due to the urgency we ask the Commission to judge the proposal until the end of the year 2012. As soon as the effective single supervisory mechanism involving ECB will be established, under proper decision ESM could have the chance to recapitalize the banks in eurozone directly".

Available at: http://www.consilium.europa.eu/uedocs/cms_data/docs/pressdata/en/ ec/131359.pdf

11 COMMUNICATION FROM THE COMMISSION TO THE EUROPEAN PARLIAMENT AND THE COUNCIL: „A Roadmap towards a Banking Union“. In: Brussels, September 12, 2012, year 2012, No. 510, COM.

Available from: http://eur-lex.europa.eu/LexUriServ/LexUriServ.do?uri=COM:2012:0510: FIN:EN:HTML

12 Directive 2013/36/EU of the European Parliament and of the Council of 26 June 2013 on access to the activity of credit institution and the prudential supervision of credit institutions and investment firms, amending Directive 2002/87/EC and repealing Directives 
2. Common European system of deposits insurance

3. Common European system for the banking sector restructuring

4. Single European banking supervision

The difference in adjustment of deposits insurance systems as well as absence of a unified resolution framework according to the explanatory memorandum represents the obstacle for creation or functioning of the single internal market. Adding the economic crisis in progress and the general weakening of the trust not only into the credit institutions, it seems to be for the European Union more than necessary to take the steps for saving or rather even recovering the credibility of the whole financial system.

Concerning these issues the countries often proceed according to their own meaning and hurriedly implemented various measures to prevent a panic and therewith connected runs on the credit institutions. So far the directive from the year $2009^{13}$ is the latest effective initiative.

Although the system is harmonized, the unification concept in all countries of the European Union is constantly more and more discussed and instead of harmonization there can be seen an effort to come to a direct regulation ${ }^{14}$. In the explanatory memorandum of the proposed regulation there is stated that the existence of more than forty various deposit insurance systems (hereafter „systems“) on the European Union's territory is the predominant problem and further also their underfunding. To solve these particular problems in the text there are stated the following measures:

1. Simplification of the existing adjustment

2. Shortening of the maturity period and improvement of reporting obligations

3. Increase of the financial systems capacity

4. Borrowing facilities, i.e. the possibility to transfer the funds between the systems of individual countries

The proposal stems from article 47, paragraph 2 of the Treaty on the Functioning of the European Union (hereafter „TFEU“), which is the legal basis for the adoption of measures the purpose of which is to create the internal market within the financial services.

2006/48/EC and 2006/49/EC, Regulation (EU) No. 575/2013 of the European Parliament and of the Council of 26 June 2013 on prudential requirements for credit institutions and investment firms and amending Regulations (EU) No. 648/2012

13 DIRECTIVE 2009/14/EC OF THE EUROPEAN PARLIAMENT AND OF THE COUNCIL of 11 March 2009 amending Directive 94/19/EC on deposit-guarantee schemes as regards the coverage level and the payout delay.

14 Proposal for a DIRECTIVE .../.../EU OF THE EUROPEAN PARLIAMENT AND OF THE COUNCIL on Deposit Guarantee Schemes In: Available at: http://ec.europa.eu/internal_market/bank/docs/guarantee/20100712_proposal_en.pdf 
More clear specification of the deposits definition is a positive aspect of the proposal. According to this proposal only instruments payable in entire extent can be considered as the deposits, i.e. not structured products, certificates or credit bonds. This prevents the systems from unnecessary investment risks. In addition all systems have to be subjected to continuous supervision and have to conduct regularly the exercise tests of all systems. The member states are also expressly authorized for the mergers of the Deposit Guarantee Schemes.

From the insurance there are obligatorily excluded deposits predominantly of the public authorities and financial institutes of any type, which has been modified as the facultative possibility so far.

On the contrary at present the deposits of non-financial companies and deposits in other currencies that are currencies of the member states are considered as the obligatory insured.

Although the maximum amount of insurance is not changing in the proposal there is explicitly stated the possibility to agree higher limit but only in specific cases and for a limited time. ${ }^{15}$ There is also significant reduction in time for deposit withdrawals. Currently the Directive requires the member states to ensure deposit withdrawals within 20 days from the moment when the system is notified on the institution bankruptcy. The proposed adjustment envisages with gradual period shortening up to final 7 days, but right up until the year 2024 .

In the regulation there is also set out quite new way of the systems funding, consisting of four phases, whereas not all are obligatory, only their order is.

Firstly after the transitional period of ten years the systems have to dispose with the sum in amount of 1, $5 \%$ of eligible deposits. Only if it appears in connection with the institution bankruptcy that these funds are insufficient, the second phase is going to turn up.

This one insists in ex post obligation of all institutions of the state in question to settle extraordinary contributions, namely up to the amount of $0,5 \%$ of eligible deposits. ${ }^{16}$ The proposed conception drafted here is the compromise result of theoretical considerations if it is better to finance the systems ex post or ex ante, ${ }^{17}$ thus the funds in the proposed model settled ex ante amount to $3 / 4$ of the fund volume, while those settled ex post amount to $1 / 4$.

Thirdly the borrowing facility enables the system, which lacks the funds, to secure a loan from all other systems of the deposits insurance in the EU. Those

15 For instance deposits coming from real estate transactions but for a maximum of 12 months.

16 However there is the possibility for the supervisory authorities to release the institution from this obligation namely in case that the payment could threaten it.

17 See more at: Funding of Deposit Insurance Systems. In: [online]. [cit. 2014-02-13]. Available at: http://www.iadi.org/docs/funding\%20final\%20guidance\%20paper\%206_ may_2009.pdf 
ones are even obliged to provide the funds in case of necessity namely even without delay up to the amount of $0,5 \%$ of their eligible deposits. The systems of individual countries will subscribe to the contribution relatively according to the amount of their eligible deposits. ${ }^{18} \mathrm{For}$ the purpose to ensure repayment, these systems are entitled to enter into the depositors' claims on behalf of the institution being in bankruptcy. The last chance how to save deposits of the troubled institutions is the alternative financing in case there is a lack of the funds from the previous steps. However the funding through the ECB is expressly prohibited. ${ }^{19}$ But this mechanism will start its implementation after ten years, i.e. when the systems will be filled with the needed liquidity. Primarily the system's funds should be used for the depositors' redemption. But this does not protect to use them for the problem solution in accordance with the subvention rules. In order to avoid the funds depletion on account of the bank's uninsured creditors, this way of the funds utilization has to be limited.

In this respect the interconnection with the fund for the banks' problem solution will be important, i.e. with the so called third pillar. In my opinion the separation of these pillars itself is problematic, because they both are significantly interconnected. This fact strengthens even the reality that in comparison with the original proposal the European Deposit Insurance Fund has been excluded from the proposal and replaced with the above mentioned system of borrowing facilities. This leads to a very close conjunction with the fund which ought to be established in the framework of the Single Resolution Mechanism (hereafter "SRM“). The essence is that if a credit institution despite the Single Supervision Mechanism (hereafter "SSM") being newly under control of ECB finds itself in serious problems, there will be a single and in advance specified procedure, which will prevent the uncontrolled defaults. The ECB notice will be the releasing mechanism that the bank has serious financial difficulties. The regulation also counts with the possibility that the troubled institutions will "sign up" themselves. The specific solution ought to be prepared by the Committee ${ }^{20}$, but the formal decision making has to be under control of the European Commission. There has to be the support of primary law to establish a body with the decisionmaking power. With respect to the consentaneity principle to be applied for the primary law changes, it is very unlikely to find political will for such a change in particular in Germany and Nordic countries, because their deficits are, at least in comparison with the south of Europe, relatively low. Because the SRM regulation is the secondary legal act, it cannot create new power beyond the framework of the founding treaties.

18 The Regulation determines five year maturity period under assumption that the system will obtain the funds for its payment through the selection of new contributions.

19 See Article 123 TFEU.

20 The committee should be composed of representatives of the European Commission, central banks, where the problematic banks have its residence, branch offices and subsidiaries. 
This is the reason why as the legal basis has been marked article 114, par $1^{21}$ of the TFEU, relating to the internal market. The foundation of the fund, which ought to be funded by contributions of the banking sector, is a part of this mechanism ${ }^{22}$. The amount would be based on the bank's risk profile, whereas the riskiness would be judged by the European Union. But the question is, if this construction does not contradict with the article 114, par 2 of TFEU. In this article there is stated that article 114, par $1^{23}$ cannot be used for the provisions relating to taxes, nevertheless „contribution of banking sector“, in my opinion, can be subsumed under the term tax. This would mean that the regulation in question cannot be the execution of the article 114 of TFEU and thus it has no reliance in the primary law.

In addition to the fund adjustment I see the fund's volume as very problematic. The funds will be, in my opinion, also insufficient for the banks' capitalization leaving alone the settlement of claims for the insured deposits. With regard to the ratio of the bank's balance sheets to the countries' GDP, 55 billion is the very conservative estimate. Some estimates indicate that the European banks will need 50 billion for „cleaning“, but others even 900 billion Euros. ${ }^{24}$ I think that currently nobody can state this with certainty mainly with respect to distrust concerning the bank balance sheets of the European institutions. ${ }^{25}$ Therefore ECB has been empowered to perform so called „Comprehensive assessment Analysis“26, i.e. stress tests. These should be completed in November 2014 i.e. at the time when ECB will take over the tasks in the field of single supervision. The tests themselves should assess all of the bank assets, i.e. even so called non-performing loans ${ }^{27}$, restructured loans but also exposures towards foreign countries.

21 Wording of Article 114 par 1 TFEU: , Save where otherwise provided in the Treaties, the following provisions shall apply for the achievement of the objectives set out in Article 26. The European Parliament and the Council shall, acting in accordance with the ordinary legislative procedure and after consulting the Economic and Social Committee, adopt the measures for the approximation of the provisions laid down by law, regulation or administrative action in Member States which have as their object the establishment and functioning of the internal market."

22 It is considered $1 \%$ of covered deposits of the banks of all participating countries. Anticipated 55 billion Euros would be obtained after ten years.

23 See above

24 See e.g."”True" euro zone stress test could show $\$ 1$ trillion hole in banks - study. [online]. [cit. 2014-01-29]. Available at: http://www.reuters.com/article/2014/01/16/eurozonestresstests-estimate-dUSL5N0KQ2BR20140116

25 It's more than obvious if you looked at the market and book values of 10 biggest euro-area banks. Their market to book value ratio is $54.9 \%$ in comparison with $97.5 \%$ in the top 10 United States banks.

26 Empowerment contains article 33, par 4 COUNCIL REGULATION, through which the central bank is entrusted with special tasks concerning policies relating to the prudential supervision of the credit institutions COM (2012) 511

27 That means loans approaching to default, e.g. according to IMF they are loans 90 and more days overdue. But this criterion is problematic because the term "non-performing loan“ is not defined in the European legislation. 
Probably the biggest problem, which ECB will have to cope with, is the rating of the government bonds especially of the southern wing of Europe ${ }^{28}$. The actual ECB testing has, in my opinion, one basic deficit.

Tests, which ECB has started in the last year, stem from the actual capital definitions especially in this respect important definition of indicator Tier 1. However given the effectiveness of so called „CRD IV Package ${ }^{\text {“29 }}$, this capital will be defined more strictly since January $2015^{30}$, and therefore the banks will not be able to include some of the current items into it. Thus the evaluation results will be distorted. In addition in the course of testing it is necessary to hold Tier 1 capital on at least $6 \%^{31}$ threshold, although from the next year the percentage ratio will increase, and the banks will have to hold it at $8 \%$. Therefore the question is how the data, now collected and assessed by ECB, will be relevant. Moreover it is interesting to note that even in October of the last year ECB declared that the threshold $8 \%$ is needed, because its observance reveals all possible types of risks that may arise in the future. ${ }^{32}$

In doing so the experience with the stress tests of EBA over Belgian Dexia ${ }^{33}$ in the year 2011 may, in my opinion, serve as an example of what ECB should avoid, if it doesn't want to be discredited immediately in the very beginning of its new role.

Finally in the transitional provisions of the proposal there is the Commission instrument for preparation report on the whole system functioning. This one should be submitted by the end of the year 2015 together with prospective legislative text of the only system creation within the whole union. Once again

28 About rating in the E. U. see more at: KOHAJDA, Michael. Ratingové agentury pohledem právníka. Právní rádce, 2012, roč. 20, č. 4, s. 44 - 47. ISSN: 1210-4817. p. 45

29 Directive 2013/36/EU of the European Parliament and of the Council of 26 June 2013 on access to the activity of credit institution and the prudential supervision of credit institutions and investment firms, amending Directive 2002/87/EC and repealing Directives 2006/48/EC and 2006/49/EC, Regulation (EU) No. 575/2013 of the European Parliament and of the Council of 26 June 2013 on prudential requirements for credit institutions and investment firms and amending Regulations (EU) No. 648/2012

30 So what can and what cannot be considered as so called CET1 - „Common Equity Tier 1“, which is the basic one for calculation of the capital adequacy of the institution.

31 ECB Said to Favor 6\% Capital Requirement in Stress Test. [online]. [cit. 2014-01-29]. Available at: http://www.bloomberg.com/news/2014-01-15/ecb-said-to-favor-6-capitalrequirement-in-stress-test-of-anks.html

32 ECB Capital Definition Tougher in Stress Test than Review [online] [cit. 2014-01-29]. Available at: http://www.bloomberg.com/news/2013-10-23/ecb-applies-8-capital-bufferto-124-banks-in-asset-test.html

33 During stress tests EBA has been specified, that even at the worst scenario that may arise, the capital value of tier 1 doesn't drop under $12 \%$, which makes Dexia the most safety bank in Europe. Dexia then, based on the report of EBA, has received rating as high as possible, i.e. AAA. But at about two months later due to the huge losses on Greek bonds the bank has been saved from default only with „government injection , in amount of 4 billion Euros. 
there is to be considered what has already been proposed, i.e. creation of one union fund for all institutions and depositors within the whole territory of the European Union.

At theoretical level I suppose that the interconnectivity will be very important or if you like clarification of relationships among the systems and SRM. Namely in the situation when the European Deposit Guarantee Scheme will be mandatory within the all of "twenty eight", while SRM will be mandatory only in the countries the currency of which is Euro, or in the countries that will join the banking union voluntarily. I am also sceptical towards ex post financing, although only the relative one. Namely it may be presumed the doubts of willingness to fund the faults of the others so the simplest solution for the institutions in question will be to pass on the costs on depositors through an increase in service charges. Despite the fact that these "loans" will have to be repaid within five years, I can imagine more profitable investments, which the institutions could do with free funds.

Already once proposed the single system for the whole European Union is, in my opinion, also the way in wrong direction. Although I think that the concept of the deposits insurance is very useful institute, the proposed system may have negative consequences. Generally I also do not share the Commission view that the legal forms diversity deforms the market. More likely reversely, for the subjects at the market there is nothing better than free competition in the provision of services of a large number of subjects. In my opinion, two situations can occur.

In one scenario the European fund can have sufficient capital to help the problematic institutions. Despite this positive aspect, the concept could interfere with the market environment and lead to the laxity of the market operators. One of the key attributes to be evaluated by the potential bank client should be the ability of the institution to meet its obligations. In the proposed system he will have his money "sure“, and so he need not to put emphasize on obtaining information on the institution and its financial situation. In addition thereby the banks loose the element of external supervision. From the viewpoint of banks this increases the risk of moral hazard, because they can suppose that they contribute ex ante on ex post capitalization.

The opposite scenario, and in my opinion more likely, will be that the European fund will not have sufficient capital. Due to the size of the banking sector in Europe, as I have stated earlier, it can be hardly imagined how high the charges should the bank contribute to the fund in order to cover defaults of the so called „too big to fail" bank. The ultimate consequence should be probably capitalization from the side of countries or their taxpayers. With respect to the fact that in the explanatory memorandums of almost all European initiatives in response to the actual crisis there is stated as the basic goal to pass on the burden of capitalization from taxpayers to the institutions, this model cannot be considered as too 
effective one. Moreover in general I suppose that even it is necessary to protect depositors in a certain measure, the regulation should not replace the vigilance of the market subjects namely in context of the already very significant legislative hypertrophy.

\section{The Federal Deposit Insurance Corporation}

The federal deposit instance corporation was founded in 1933 by the „Banking Act ${ }^{\text {“34, }}$, so it's the oldest deposit insurance scheme in the world. It is headed by the quinary Board of governors ${ }^{35}$ and has a special position as an independent government agency that protects depositor's funds. The aim of this early creation was to prevent bank from failures because of the Great Depression. The main difference between the European Union and the United States approach is that the FDIC is responsible for both deposit guarantee and resolution schemes. The primary purposes of FDIC are to insure and protect the deposits of insured banks and to resolve failed banks. Deposits are divided into categories ${ }^{36}$ within each of them depositors are insured up to 250000 USD. In this regard there's a huge loophole in the amounts between mentioned regions. While in the EU there's a 100000 EUR limit, in the United States it could be millions, if you are able to diversify your assets shrewdly.

FDIC or in particular its fond ${ }^{37}$ is funded entirely by fees from member banks, savings associations and interest earnings on its investment portfolio of United States Treasury securities. No federal or state tax revenues are involved, although it is guaranteed indirectly by the taxpayers. As it is mentioned on the official web: „FDIC deposit insurance is backed by the full faith and credit of the United States government" 38 This would be very interesting to see what would happen if such a situation occurred. Although it is written on an official government website, there is no legal document that would make this promise binding. On the other hand there is an explicit legal provision that allows the United States Department of the Treasury (hereafter "Treasury") to provide a line of

34 The statute is called as a banking act on the ground that its content is aimed at banking reforms in general. The legislation is also referred to as the "Glass-Steag all Act" after its proposers. In addition to the FDIC establishment, the main outcome of this Act was to ban commercial banks from an affiliation with security firms and security activities.

35 The three of them are appointed by the United States president after the Senate approval. Two ex officio members are the Comptroller of the Currency and the director of the Consumer Financial Protection Bureau.

36 There are: 1)Single ownership accounts, 2) Certain retirement accounts, 3) Joint accounts, 4) Revocable trust accounts, 5) Irrevocable trust accounts, 6)Employee Benefit Plan accounts, 7) Corporation/Partnership/Unincorporated Association accounts, 8) Government accounts

37 Till 2006, there were two separate FDIC funds - the Bank Insurance Fund and the Savings Association Insurance Fund.

38 Available at: http://www.fdic.gov/consumers/banking/confidence/symbol.html\#Full. [online]. [cit. 2014-02-11]. 
credit up to 500 billion USD to the FDIC, which it has to repay over time. The last legislation ${ }^{39}$ set the target ratio that has to be reached to $1,35 \%$ of the insured deposits $^{40}$ by the September of 2020. In accordance with the FDIC statement ${ }^{41}$, the aim should have to be reached even in 2018 .

As in the EU the FDIC insures deposits only. It does not insure investments in stocks, bonds, mutual funds, life insurance policies, annuities, or municipal securities, even if a customer purchases them from an FDIC-insured bank or savings association. Treasury securities purchased by an insured depository institution on a client's behalf are not insured either.

The EU proposal is inspired in the United States law in the institute also known as "Living will". The law requires systemic nonbank financial companies and large bank holding companies ${ }^{42}$ to submit ${ }^{43}$ a plan for their resolution in the event of financial distress or default.

I have mentined above and contrary to the EU proposals in the United States there are newly $\mathrm{y}^{44}$ regulated and insured systematically important financial institutions ${ }^{45}$ as well. This means, apart from Credit Unions ${ }^{46}$ which are not covered by the insurance, that the FDIC scope is much wider than in the EU. The decision to deem a failing financial firm "systemic" will be made by the FDIC and Federal Reserve Board in conjunction with the Treasury. After this co-decision it's up to FDIC solely, what will be done. In the event of a bank failure, the FDIC has two possible capacities.

Firstly, it has to pay insurance to the depositors up to the insurance limit. In the second phase, FDIC role can be described as the "receiver" of defaulted banks. It has to choose among options that were given to it by the law. The first step is called as conservatorship and it means that Board of governors will replace the management. This is referred to as "prompt corrective action". Than the Board can give binding instructions as follows:

Restructuring the bank as a "bad bank" and a "good bank".

Selling off pieces of the bank or the whole bank

39 Dodd-Frank Wall Street Reform and Consumer Protection Act adopted in 2010

40 The worst reserve ratio was at 0.17 percent at the end of 2011.

41 FDIC Says Deposit Insurance Fund Should Recover by Late 2018. [online]. [cit. 2014-0211]. Available at: http://www.bloomberg.com/news/2012-04-23/fdic-says-deposit-insurance-fund-recovery-expected-by-late-2018.html

42 Those with at least 50 billion USD in assets

43 The Plan has to be submitted to the FDIC, Federal Reserve, and Financial Stability Oversight Council

44 Since the Dodd-Frank Wall Street Reform and Consumer Protection Act adoption in 2010

45 It means institutions whose failure may trigger a financial crisis and it includes large hedge funds and traders, large insurance companies, and various types of systemically important financial market utilities.

46 As listed above this term come under the credit institution definition, so it's covered by the insurance. The Czech equivalent would be "družstevní záložna". 
- Providing or arranging funding for the bank from official bodies or the private sector

- Forcing creditors to do a debt to equity conversion

- Determining the division of losses among stakeholders

This powers are typically given to the authorities which supervise the bankruptcies. Furthermore FDIC is empowered to make a very quick decisions and most important, without the consent of the stakeholders. It's very often that bank shuts down on Friday and opens on Monday, after takeover. In general this is very important because the Board can intervene while the institution is undercapitalized but still solvent. In my opinion, this is one of the biggest differences in the aprroach in comparison with the EU. This decision in the EU has to make European Comission comprising of 28 different state representatives. This will make the resolution process too slow and the decision will be politically affected. I think this is the biggest EU loophole at all decision-making processes. The outcome from that is very clear in figures.

FDIC numbers demonstrates that since 2008, 13 banks received FDIC support, while in the euro area and the rest of the $\mathrm{EU}$, there are 50 cases of state aid support for euro-area banks, and 38 for the rest of the EU. ${ }^{47}$ Since 2010, the FDIC has not started a new support Programme for any bank. The FDIC reports that 494 banks failed in the US from 2008 to $2013^{48}$. In Europe, there is no official data source but unofficial estimates hovers in figures of 49 in the euro area and 64 in the rest of the EU. ${ }^{49}$ This figure clearly shows how reluctant the EU and its bodies are.

The other big problem is the low equity ${ }^{50}$ level in EU. Problem is that there is a very low interconnectivity within EU member states. Balance sheets of banks are huge compared to the GDP of states compared to the United States, but only on an individual level. EU states have to liquidate banks through the European Stability Mechanism (hereafter as "ESM") ${ }^{51}$ or cross-border consolidation. Only after that we can break the vicious circle between sovereigns and banks. Personally, I would prefer mergers. In my opinion it's the only way to liquidate bank without the state aid even though this would create even more "too big to fail" banks. Other ways are either insufficient, as in the case of Resolution fond, or inappropriate, as in the ESM case. By in-appropriation it is meant that this way

47 OECD (2013) Financing SMEs and Entrepreneurs 2013: An OECD Scoreboard. Final Report. [online]. [cit. 2013-12-10].

48 „The neglected side of banking union: reshaping Europe's financial system“ André Sapir, Guntram B. Wolff 2013 online]. [cit. 2013-18-12].

49 For details see: Data downloaded on February 2nd 2014 from http://openeconomics. net/failed-bank-tracker"/

50 Also the return on equity has been much lower at the end of 2012. For the data of ten largest banks in the EU was at $1.7 \%$ in comparison with $8.9 \%$ in the United States.

51 ESM is an international organization that was created to provide instant access of financial assistance for its member states. 
of capitalizing in fact will rely on taxpayers. Nevertheless this system, build up on cross-border merges, is conceivable only with a strict single supervision and resolution mechanism in the whole European Union.

\section{Conclusion}

The European financial system will have to pass very significant changes if it wants to move out of the place. It is evident that Europe has only two possibilities how to continue. At first the Europe will return one step or a few steps back. By this I mean abandonment of the single currency and return of some power back to the national authorities. The second possibility of the European Union is to integrate more. Now it is perhaps obvious even to the supreme representatives of EU, that the banking union and monetary union are not possible without the fiscal one. Therefore firstly it is crucial to find political consensus on the future of the Europe. Perhaps the most pressing problem of Europe, maybe with exception for the state deficits, is banking sector and it's under- capitalization. At present nobody knows how much exactly the banks will need. It should be changed, currently ECB runs tests. After evaluation it will be necessary to find consensus in the sphere of the single resolution mechanism. But such a model should be found, which could be implemented across the whole EU, therefore to carry out in practice the merger of the so called second and third pillar of the Bank union. In this regard inspiration can be found in the United States. Their system is functional and operational. ${ }^{52}$ It will be crucial, as it is in the United States, to find operational authority or institution which will not be subjected to political pressure. It must be the authority that will be adequately empowered, but particularly it will be able to make decisions quickly, if possible, without the necessity of the creditors' consent. I suppose that in the initial stage it will be better to let some bank fail. Although these steps will not be certainly politically popular, they are required for "market cleaning". What the United States already have gone through, the Europe is still expecting. The problem of Europe still insists in disability to act in a coordinated manner. Instead of that the debts of institutions and countries are "socialized" among the others. However the only result of such acting is putting off the problem until the future. This is the very expensively bought time, which moreover the Europe wasted to a large extent. I think that today it is already obvious that great part of this "loans" will never be repaid. What happens next it is difficult to estimate since the taxpayers' money also run out once.

52 A good example of it can be IndyMac bank in comparison with the Bank of Cyprus. IndyMac was bank in California with 32 billion USD in assets. It had serious problems in 2008. The FDIC took over this bank and sold it in 2009. I think that most of Europeans didn't even realize what was going on. The Bank of Cyprus had 37 billion EUR in assets and I think I don't have to describe what happened in this case, because almost everyone has heard about it. 